\title{
Evaluation of a Novel Poultry Litter Amendment on Greenhouse Gas Emissions
}

\author{
Kelsey Anderson, Philip A. Moore Jr. *, Jerry Martin and Amanda J. Ashworth (D) \\ USDA-ARS, Plant Sciences 115, University of Arkansas, Fayetteville, AR 72701, USA; \\ kelsey.anderson@usda.gov (K.A.); jerry.martin@usda.gov (J.M.); amanda.ashworth@usda.gov (A.J.A.) \\ * Correspondence: philip.moore@usda.gov
}

Citation: Anderson, K.; Moore, P.A.,

Jr.; Martin, J.; Ashworth, A.J.

Evaluation of a Novel Poultry Litter Amendment on Greenhouse Gas

Emissions. Atmosphere 2021, 12, 563.

https://doi.org/10.3390/

atmos12050563

Academic Editor: Jacek Koziel

Received: 1 April 2021

Accepted: 27 April 2021

Published: 28 April 2021

Publisher's Note: MDPI stays neutral with regard to jurisdictional claims in published maps and institutional affiliations.

\begin{abstract}
Gaseous emissions from poultry litter causes production problems for producers as well as the environment, by contributing to climate change and reducing air quality. Novel methods of reducing ammonia $\left(\mathrm{NH}_{3}\right)$ and greenhouse gas $(\mathrm{GHG})$ emissions in poultry facilities are needed. As such, our research evaluated GHG emissions over a $42 \mathrm{~d}$ period. Three separate flocks of 1000 broilers were used for this study. The first flock was used only to produce litter needed for the experiment. The second and third flocks were allocated to 20 pens in a randomized block design with four replicated of five treatments. The management practices studied included an unamended control; a conventional practice of incorporating aluminum sulfate (referred to as alum) at $98 \mathrm{~kg} / 100 \mathrm{~m}^{2}$ ); a novel litter amendment made from alum mud, bauxite, and sulfuric acid (alum mud litter amendment, AMLA) applied at different rates (49 and $98 \mathrm{~kg} / 100 \mathrm{~m}^{2}$ ) and methods (surface applied or incorporated). Nitrous oxide emissions were low for all treatments in flocks 2 and $3\left(0.40\right.$ and $0.37 \mathrm{mg} \mathrm{m}^{2} \mathrm{hr}^{-1}$, respectively). The formation of caked litter (due to excessive moisture) during day 35 and 42 caused high variability in $\mathrm{CH}_{4}$ and $\mathrm{CO}_{2}$ emissions. Alum mud litter amendment and alum did not significantly affect GHGs emissions from litter, regardless of the amendment rate or application method. In fact, litter amendments such as alum and AMLA typically lower GHG emissions from poultry facilities by reducing ventilation requirements to maintain air quality in cooler months due to lower $\mathrm{NH}_{3}$ levels, resulting in less propane use and concomitant reductions in $\mathrm{CO}_{2}$ emissions.
\end{abstract}

Keywords: alum; alum mud litter amendment (AMLA); poultry; litter; greenhouse gas (GHG); methane emissions; nitrous oxide emissions

\section{Introduction}

Poultry farms have been implicated as having a negative impact on air quality and the environment due to large amounts of atmospheric ammonia $\left(\mathrm{NH}_{3}\right)$ being emitted from poultry litter (combination of bedding material, feces, and urine; [1]) during production. It is believed that $\mathrm{NH}_{3}$ emissions from poultry litter account for $27 \%$ of the total atmospheric $\mathrm{NH}_{3}$ emissions in the U.S from animal husbandry. [2]. Although $\mathrm{NH}_{3}$ is the largest atmospheric contaminant with respect to poultry production, poultry farms are also a source of greenhouse gas (GHG) emissions such as nitrous oxide $\left(\mathrm{N}_{2} \mathrm{O}\right)$, carbon dioxide $\left(\mathrm{CO}_{2}\right)$, and methane $\left(\mathrm{CH}_{4}\right)$, which contribute to global climate change [3].

According to the latest report by the U.S. Environmental Protection Agency (USEPA), the Agriculture sector accounts for $9.3 \%$ of the total GHG emissions in the U.S. [4]. Greenhouse gases in agriculture are mainly emitted from animal waste, in housing facilities, in storage faculties, during animal grazing through enteric fermentation, or during manure spreading [5]. Methane and $\mathrm{N}_{2} \mathrm{O}$ have high global warming potentials, which are 28 and 265 times greater than $\mathrm{CO}_{2}$, respectively [6]. According to USEPA [4], in 2018, $\mathrm{CH}_{4}$ emissions from manure management and enteric fermentation represent approximately 10 and $28 \%$ of total anthropogenic activities, respectively. The largest contributors of $\mathrm{N}_{2} \mathrm{O}$ emissions in the agriculture sector are livestock manure, application of synthetic and organic fertilizers, and growing N-fixing plants [4]. 
In the poultry industry, litter management during and after production contributes to GHG emissions. Given the assumption that $1.05 \mathrm{~kg}$ of litter is produced per bird [7], nearly 13 million $\mathrm{Mg}$ (14 million tons) of broiler litter is produced on U.S. poultry farms [1]. In contrast to $\mathrm{NH}_{3}$ emissions, fewer studies have researched GHG emissions from poultry houses [8-10]. The data from these studies show that poultry production is responsible for a relativity small percentage of GHG emissions [8-10]. Broilers have monogastric digestive systems, and therefore do not produce a significant amount of $\mathrm{CH}_{4}$ through enteric fermentation compared to cattle; instead, the main source of $\mathrm{CH}_{4}$ being emitted is through poultry litter $[9,11]$. The formation of $\mathrm{CH}_{4}$ occurs through anaerobic decomposition of poultry litter where oxygen, water contents, $\mathrm{pH}$ levels, and nutrient availability play a key role in $\mathrm{CH}_{4}$ production. Methane emission from the surface of poultry litter is often reported as being very minimal $[8,10]$. Since the majority of poultry litter within poultry houses is in a solid state, aerobic conditions lead to only minimal $\mathrm{CH}_{4}$ emissions being formed form the surface of the litter [9]. Nitrous oxide emissions mainly occur after poultry production, during storage and field application, through the process of nitrification and denitrification [12]. The storage of poultry litter under aerobic conditions with pockets of anaerobic conditions leads to $\mathrm{N}_{2} \mathrm{O}$ volatilization while poultry litter stored in predominantly anaerobic conditions leads to the production of methane causing a tradeoff between the two GHG emissions [13]. Carbon dioxide emissions from poultry litter occurs from the aerobic break down of uric acid as well as other organic compounds [14]. Calvet et al. [15] conducted a study on $\mathrm{CO}_{2}$ balances in broiler production and reported that broiler litter accounted for $20 \%$ of the total $\mathrm{CO}_{2}$ produced from a broiler facility.

Chemical amendments such as aluminum sulfate $\left.\left(\mathrm{Al}_{2}\left(\mathrm{SO}_{4}\right)_{3} \cdot 14 \mathrm{H}_{2} \mathrm{O}\right)\right)$, otherwise referred to as alum, are used to reduce $\mathrm{NH}_{3}$ emission from poultry litter, but only one study has evaluated the effects of alum on GHG concentrations and emissions in poultry houses. In the study, Eugene et al. [16] found no differences in $\mathrm{CH}_{4}$ and $\mathrm{N}_{2} \mathrm{O}$ emissions from alum-treated and untreated litter. However, Eugene et al. [16] did report significantly lower $\mathrm{CO}_{2}$ emissions from broiler houses treated with alum compared to untreated litter, which was due to less propane use during winter months because of lower $\mathrm{NH}_{3}$ levels which allowed reduced ventilation rates.

The substantial price increase of alum over recent decades has created a need for a cheaper litter amendment to control $\mathrm{NH}_{3}$ levels in poultry houses. One cheaper alternative that was patented by Moore [17] is alum mud litter amendment (AMLA). Alum mud litter amendment is a mixture of bauxite, sulfuric acid, and alum mud, which is an acidic solid residue formed as a byproduct during the manufacturing of alum [18,19]. Alum mud litter amendment, also called Al+Clear Plus, was manufactured by Chemtrade logistics INC. (Toronto, Ontario; Canada). Laboratory studies conducted on this new amendment showed that it was comparable to alum in reducing $\mathrm{NH}_{3}$ emissions $[17,19]$. A pen trial conducted by Anderson et al. [20] on the effects of AMLA on $\mathrm{NH}_{3}$ emissions from poultry litter showed AMLA reduced cumulative $\mathrm{NH}_{3}$ from litter as much as, and in some cases more than alum applied at the same rate. Since this amendment is manufactured mainly using alum mud (a waste product that is normally landfilled at \$32 USD ton ${ }^{-1}$ ), it should be much more cost-effective than alum. The effect of AMLA on GHG emissions has not previously been studied; therefore, the main objective of this study was to evaluate GHG emissions from poultry litter treated with AMLA in comparison to alum and untreated litter.

\section{Materials and Methods}

\subsection{Design and Treatments}

Pen trials were conducted at the poultry farm at the University of Arkansas Agricultural Research Station in Fayetteville, Arkansas. Three separate flocks of five hundred male and five hundred female 1-day-old Cobb x Cobb broiler chicks were randomly allocated to 20 pens at a density of $0.08 \mathrm{~m}^{2} \mathrm{bird}^{-1}$. The pens $(2.1 \times 1.8 \mathrm{~m} ; 50$ birds per pen) were in a single room where the atmosphere was mixed. The chicks were reared with an automatically controlled light, temperature, and ventilation $\left(0.85 \mathrm{~m}^{3} \mathrm{~h}^{-1}\right.$ per bird) 
system that had two fans producing negative pressure. The lights in the room were on for twenty-three hours and off for one hour during the night. The temperature of the room followed industry standards, starting at $32.2^{\circ} \mathrm{C}$ at the beginning of the flock and was lowered over time to $22.2^{\circ} \mathrm{C}$ at six weeks. Heat lamps were used during the first 7 days to provide the chicks with warmer temperatures. The pens had concrete floors and were equipped with one tube feeder and an automatic bell drinker and started with $5 \mathrm{~cm}$ of clean pine wood shaving for bedding (17.2 kg per pen). Each flock of birds was raised for $42 \mathrm{~d}$. Chicks were fed starter diets during the first two weeks ( 0 to $14 \mathrm{~d}$ ), grower diets during the next three weeks ( 14 to $35 \mathrm{~d}$ ), and finisher diets the last week ( 35 to $42 \mathrm{~d}$ ). The diets contained corn $(64.2 \%)$, soybean meal $(27.7 \%), 50 \%$ meat and bone meal $(2.5 \%)$, poultry oil $(2.65 \%)$, sodium chloride $(0.31 \%)$, sodium bicarbonate $(0.05 \%)$ limestone $(0.74 \%)$, dicalcium phosphate $(1 \%)$, along with vitamins, amino acids, trace metals, xylanase and phytase. Unlike the European poultry industry, where litter is cleaned out and replaced with each flock of birds, the United States poultry industry reuses litter for several flocks of birds. Due to biosecurity protocols, litter from outside sources was not allowed to be brought into the facility, and therefore the purpose of the first flock of 1000 birds was to produce the poultry litter needed for the experiment. The second flock of 1000 birds was placed one week after the first flock was removed. The third flock of 1000 birds was placed one year after the removal of the second flock (due to the longest government shutdown in U.S. history and the fear of another shutdown). The litter was tilled between each flock to break up any cake that may have formed and to enhance drying.

There were four replicates of five experimental treatments laid out in a randomized complete block design. Each of the 20 pens contained only one treatment. The five treatments used in this study were: (1) control (untreated litter), (2) $49 \mathrm{~kg}$ AMLA/100 m² incorporated, (3) $98 \mathrm{~kg}$ AMLA/100 m² incorporated, (4) $98 \mathrm{~kg}$ AMLA/100 m² surface applied, and (5) $98 \mathrm{~kg}$ alum/100 $\mathrm{m}^{2}$ incorporated. Three days prior to the placement of birds for flocks two and three, litter amendments were added to the designated pens. All litter amendments were evenly spread on the litter surface. The surface applied treatments were left untouched, while the incorporated amendments had the top 2 to $3 \mathrm{~cm}$ of the litter homogenized using a pitchfork.

\subsection{Flux Measurements and Litter Analyses}

Nitrous oxide, $\mathrm{CH}_{4}$, and $\mathrm{CO}_{2}$ flux measurements and litter samples were collected from each pen at days $0,7,14,21,28,35$, and 42 , during the second and third flocks. A plastic flux chamber attached to an Innova 1512 Photo-acoustic Multi-gas Analyzer (Innova Air Tech Instruments, Ballerup, Denmark) was used to measure $\mathrm{NH}_{3}$ and GHG gas emissions from the litter at three random locations within each of the pens; $\mathrm{NH}_{3}$ emissions were reported by Anderson et al. [20]. The static flux chamber was a cylindrical plastic container, $35 \mathrm{~cm}$ high with a $14.5 \mathrm{~cm}$ radius; with a small battery powered fan mounted inside the container to stir the air within the flux chamber. Although a static flux chamber was used it was only on the litter for a very short period where changes in gas concentrations were linear, hence, it is unlikely that the static chamber was significantly affecting the concentration gradients of the gases being measured. Greenhouse gases were measured above the litter surface at time zero. The flux chamber was then placed on the litter surface and gas measurements were recorded at $60 \mathrm{~s}$ as was done by Choi and Moore [21]. The difference between the concentration at time zero and $60 \mathrm{~s}$ was used along with the ideal gas law to estimate the gas flux for each GHG being emitted from the litter. The flux measurements were then converted to an aerial basis $\left(\mathrm{mg} \mathrm{m}^{-2} \mathrm{hr}^{-1}\right)$. Cumulative fluxes were calculated by multiplying hourly fluxes by 168 to convert to a weekly flux, then successively adding each weekly flux. A litter sample was collected using clean gloves and a putty knife (used to cut through the cake layer) from the entire litter profile at each of the three locations where fluxes measurements were taken. The depth of the litter sample changed each week as more manure was added by the birds. The litter samples were thoroughly homogenized in a clean bucket, and a subsample was refrigerated for analysis; 
the excess litter was returned to the pen. Litter samples were analyzed for moisture content, $\mathrm{pH}$, electrical conductivity (EC), ammonium- $\mathrm{N}\left(\mathrm{NH}_{4}-\mathrm{N}\right)$, nitrate- $\mathrm{N}\left(\mathrm{NO}_{3}-\mathrm{N}\right)$, and total $\mathrm{N}$ (TN). Only moisture content and $\mathrm{NO}_{3}-\mathrm{N}$ litter data will be reported in this paper. For all other litter parameter data, see Anderson et al. [20]. Moisture content was determined by oven drying a subsample of litter at $65^{\circ} \mathrm{C}$ for 1 week. Fresh litter samples were extracted using a 1:10 (litter: water) ratio and filtered through a $0.45 \mathrm{um}$ filter paper according to Self-Davis and Moore [22]. The litter extracts were analyzed for $\mathrm{NO}_{3}-\mathrm{N}$ colorimetrically on a Skalar auto-analyzer (Skalar, Buford, GA); using the salicylate-nitroprusside USEPA Method 351.2 [23].

\subsection{Data Analysis}

Statistical analyses were conducted to evaluate the effect of litter amendments on GHG fluxes and litter characteristics using the GLIMMIX procedure in SAS 9.4 [24]. The experimental design was a randomized complete block design with a two-factor, factorially arranged treatment design. Analysis of variance (ANOVA) was conducted on main effects (litter amendments and sampling date), while blocks were considered random effects. Flocks 1 and 2 were analyzed separately. Differences in means were separated using Fisher's least significant difference (LSD) test at the 0.05 probability level.

\section{Results and Discussion}

\subsection{Nitrous Oxide Emissions and Litter Nitrate Concentrations}

Nitrous oxide-N emissions ranged from 0.08 to $0.68 \mathrm{mg} \mathrm{m}^{-2} \mathrm{hr}^{-1}$ during flock 2 and from -0.09 to $1.27 \mathrm{mg} \mathrm{m}^{-2} \mathrm{hr}^{-1}$ during flock 3 (Table 1). There were no trends observed for average $\mathrm{N}_{2} \mathrm{O}-\mathrm{N}$ fluxes during either flock. These data are consistent with an emission study by Moore et al. [25] which reported low $\mathrm{N}_{2} \mathrm{O}$ variation per flock. Average and cumulative $\mathrm{N}_{2} \mathrm{O}-\mathrm{N}$ emissions (Table 1 and Figure 1, respectively) from both flocks were not affected by the additions of AMLA or alum to poultry litter. The study conducted by Eugene et al. [16] on the effects of alum on GHG emissions, also found no significant differences in $\mathrm{N}_{2} \mathrm{O}$ levels between alum and untreated litter. Nitrous oxide is produced during the denitrification portion of the $\mathrm{N}$ cycle. Denitrification is an anaerobic process where $\mathrm{NO}_{3}$ is serially reduced to nitrite $\left(\mathrm{NO}_{2}\right)$, nitric oxide $(\mathrm{NO}), \mathrm{N}_{2} \mathrm{O}$, and finally $\mathrm{N}$ gas. Bacteria play an essential role in the $\mathrm{N}$ cycle, since oxygen is excluded during denitrification, bacteria can use $\mathrm{NO}_{3}, \mathrm{NO}_{2}$, and $\mathrm{NO}$ as terminal electron acceptors for respiration [4]. For large levels of $\mathrm{N}_{2} \mathrm{O}$ to be emitted, poultry litter must first be aerobic, which results in the mineralization of organic matter releasing $\mathrm{NH}_{3}$, which is then converted to $\mathrm{NO}_{3}$ through nitrification. Before the start of each flock and prior to the application of the treatments, litter was tilled to break up cake that formed during the previous flock, which likely created aerobic conditions within the litter. Such aerobic conditions are ideal for the formation of $\mathrm{N}_{2} \mathrm{O}$, however, under high litter moisture, denitrification is expected to form $\mathrm{N}_{2}$ with little to no $\mathrm{N}_{2} \mathrm{O}$ being produced [5]. There were no treatment effects on the moisture content of litter for either flock [20]. If the moisture content of the litter would have varied by treatment, then perhaps differences in $\mathrm{N}_{2} \mathrm{O}$ emissions would have been observed.

Litter $\mathrm{NO}_{3}-\mathrm{N}$ concentrations as a function of time for flock 2 and 3 are shown in Figure $2 \mathrm{a}, \mathrm{b}$, respectively. The highest concentrations of $\mathrm{NO}_{3}-\mathrm{N}$ were observed during the first 2 weeks ( 0 to $14 \mathrm{~d}$ ) of flock 3 . Chastain et al. [26] noted aerated poultry litter will result in a significant amount of $\mathrm{NO}_{3}-\mathrm{N}$. The increased aeration from tilling prior to the start of flock 3 , along with the low moisture content (Table 2) of the litter, created perfect conditions for high $\mathrm{NO}_{3}-\mathrm{N}$ levels in the litter. There were no significant differences in $\mathrm{NO}_{3}-\mathrm{N}$ concentrations between untreated control litter and litter treated with AMLA or alum, during flock 2. However, during the first 2 weeks ( 0 to $14 \mathrm{~d}$ ) of flock 3 , high rates of incorporated and surface applied AMLA, and alum litter treatments resulted in significantly lower $\mathrm{NO}_{3}-\mathrm{N}$ concentrations compared to the control litter. From day 0 to 14 of flock 3, litter treated with AMLA and alum reduced the $\mathrm{pH}$ of litter below $\mathrm{pH} 7$ [20]. The optimal $\mathrm{pH}$ for nitrifying bacteria is between $\mathrm{pH} 7.0$ and 8.0 [27]; therefore, the control litter, 
which had a pH greater than 7 , had higher $\mathrm{NO}_{3}-\mathrm{N}$ levels. When the moisture content of the litter was greater than $30 \%$, (Table 2), the $\mathrm{NO}_{3}-\mathrm{N}$ within the litter was readily converted to $\mathrm{N}$ gas and was emitted into the air, thus explaining the near zero $\mathrm{NO}_{3}-\mathrm{N}$ values observed for the majority of flock 3 (days 21 through 42 ).

Table 1. Average nitrous oxide flux $\left(\mathrm{mg} \mathrm{N}_{2} \mathrm{O}-\mathrm{N} \mathrm{m}^{-2} \mathrm{hr}^{-1}\right)$ for flock 2 and 3 by treatment by day.

\begin{tabular}{|c|c|c|c|c|c|c|c|c|}
\hline \multirow{2}{*}{ Treatment } & \multicolumn{7}{|c|}{ Day } & \multirow{2}{*}{ Avg. } \\
\hline & 0 & 7 & 14 & 21 & 28 & 35 & 42 & \\
\hline & \multicolumn{8}{|c|}{ Flock 2} \\
\hline Control & $0.43 a+$ & $0.28 \mathrm{a}$ & $0.48 \mathrm{a}$ & $0.50 \mathrm{a}$ & $0.42 \mathrm{a}$ & $0.68 \mathrm{a}$ & $0.08 \mathrm{a}$ & $0.41 \mathrm{a}$ \\
\hline $49 \mathrm{~kg}$ AMLA $/ 100 \mathrm{~m}^{2}$ incorporated & $0.50 \mathrm{a}$ & $0.44 \mathrm{a}$ & $0.54 a$ & $0.62 a$ & $0.38 \mathrm{a}$ & $0.19 \mathrm{a}$ & $0.23 a$ & $0.41 \mathrm{a}$ \\
\hline $98 \mathrm{~kg}$ AMLA $/ 100 \mathrm{~m}^{2}$ incorporated & $0.22 \mathrm{a}$ & $0.32 \mathrm{a}$ & $0.58 \mathrm{a}$ & $0.56 \mathrm{a}$ & $0.37 \mathrm{a}$ & $0.46 \mathrm{a}$ & $0.28 \mathrm{a}$ & $0.40 \mathrm{a}$ \\
\hline $98 \mathrm{~kg}$ AMLA $/ 100 \mathrm{~m}^{2}$ surface applied & $0.48 \mathrm{a}$ & $0.44 a$ & $0.52 a$ & $0.59 a$ & $0.48 \mathrm{a}$ & $0.16 \mathrm{a}$ & $0.15 a$ & $0.40 \mathrm{a}$ \\
\hline \multirow[t]{2}{*}{$98 \mathrm{~kg}$ alum $/ 100 \mathrm{~m}^{2}$ incorporated } & $0.48 \mathrm{a}$ & $0.47 \mathrm{a}$ & $0.47 \mathrm{a}$ & $0.50 \mathrm{a}$ & $0.31 \mathrm{a}$ & $0.22 \mathrm{a}$ & $0.22 \mathrm{a}$ & $0.38 \mathrm{a}$ \\
\hline & \multicolumn{8}{|c|}{ Flock 3} \\
\hline Control & $-0.05 a$ & $0.05 \mathrm{a}$ & $0.59 a$ & $1.27 \mathrm{a}$ & $0.79 a$ & $0.44 \mathrm{a}$ & $0.10 \mathrm{a}$ & $0.46 \mathrm{a}$ \\
\hline $49 \mathrm{~kg}$ AMLA $/ 100 \mathrm{~m}^{2}$ incorporated & $0.05 \mathrm{a}$ & $0.03 a$ & $0.39 a$ & $0.60 \mathrm{a}$ & $0.91 \mathrm{a}$ & $0.41 \mathrm{a}$ & $0.13 a$ & $0.36 \mathrm{a}$ \\
\hline $98 \mathrm{~kg}$ AMLA $/ 100 \mathrm{~m}^{2}$ incorporated & $0.05 a$ & $0.22 \mathrm{a}$ & $0.37 \mathrm{a}$ & $0.64 \mathrm{a}$ & $0.67 \mathrm{a}$ & $0.79 \mathrm{a}$ & $0.29 \mathrm{a}$ & $0.43 a$ \\
\hline $98 \mathrm{~kg}$ AMLA $/ 100 \mathrm{~m}^{2}$ surface applied & $0.08 \mathrm{a}$ & $0.14 \mathrm{a}$ & $0.40 \mathrm{a}$ & $0.63 a$ & $0.72 \mathrm{a}$ & $0.50 \mathrm{a}$ & $0.06 a$ & $0.36 \mathrm{a}$ \\
\hline $98 \mathrm{~kg}$ alum $/ 100 \mathrm{~m}^{2}$ incorporated & $-0.09 a$ & $0.13 a$ & $0.17 a$ & $0.67 \mathrm{a}$ & $0.57 \mathrm{a}$ & $0.38 \mathrm{a}$ & $-0.06 a$ & $0.25 \mathrm{a}$ \\
\hline
\end{tabular}

+ Values in columns followed by different letters indicate significant $(p<0.05)$ differences in means within each date and flock.

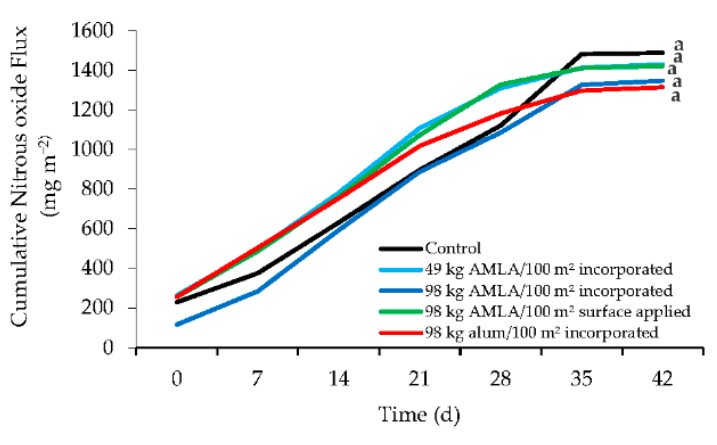

(a)

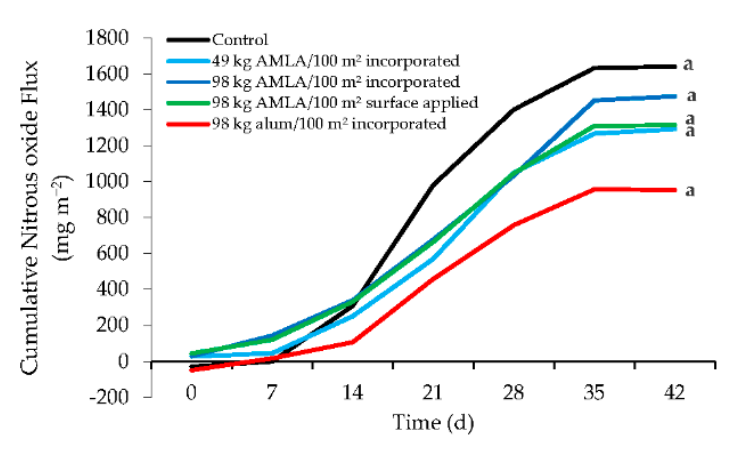

(b)

Figure 1. Cumulative nitrous oxide flux $\left(\mathrm{mg} \mathrm{N}_{2} \mathrm{O}-\mathrm{N} \mathrm{m}^{-2}\right)$ for (a) flock 2 and (b) flock 3 as a function of time. Treatments on day 42 not sharing a common letter are significantly different $(p<0.05)$.

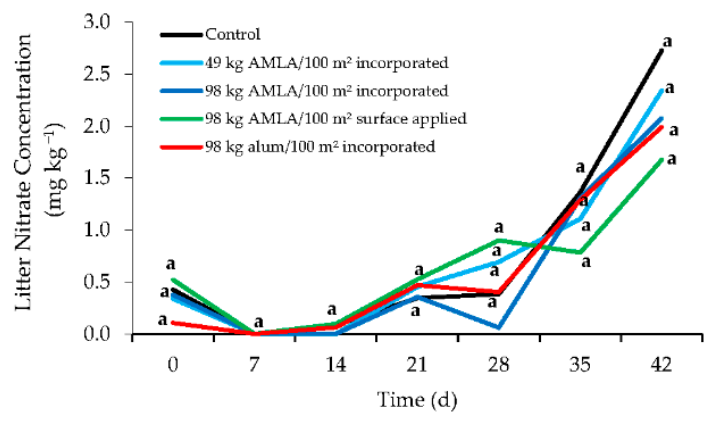

(a)

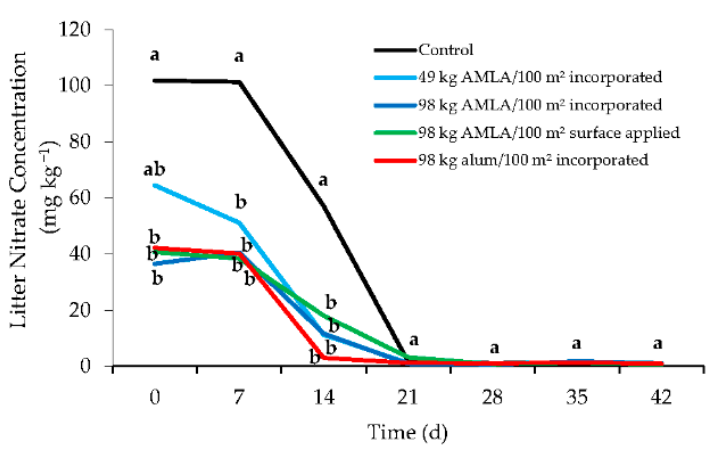

(b)

Figure 2. Average nitrate litter concentrations ( $\mathrm{mg} \mathrm{NO}-\mathrm{N} \mathrm{kg}^{-1}$ ) for (a) flock 2 and (b) flock 3 as a function of time. Treatments not sharing a common letter are significantly different $(p<0.05)$. 
Table 2. Average litter moisture (\%) flock 2 and 3 by treatment by day.

\begin{tabular}{ccccccccc}
\hline \multirow{2}{*}{ Flock } & \multicolumn{7}{c}{ Day } & Avg. \\
\cline { 2 - 8 } & $\mathbf{0}$ & $\mathbf{7}$ & $\mathbf{1 4}$ & $\mathbf{2 1}$ & $\mathbf{2 8}$ & $\mathbf{3 5}$ & $\mathbf{4 2}$ & \\
\hline Flock 2 & 36.0 & 30.6 & 30.1 & 30.0 & 37.9 & 43.0 & 43.4 & 35.9 \\
Flock 3 & 16.4 & 15.4 & 26.8 & 37.4 & 40.9 & 47.7 & 50.2 & 33.5 \\
\hline
\end{tabular}

\subsection{Methane Emissions}

Methane emissions, like $\mathrm{N}_{2} \mathrm{O}-\mathrm{N}$ emission, were also low, ranging from -7.84 to $81.8 \mathrm{mg} \mathrm{m}^{-2} \mathrm{hr}^{-1}$ during flock 2 and from -167.2 to $178.9 \mathrm{mg} \mathrm{m}^{-2} \mathrm{hr}^{-1}$ during flock 3 (Table 3). These low $\mathrm{CH}_{4}$ emissions are consistent with emission studies by Wathes et al. [10], Miles et al. [8], and Burns et al. [28], who also reported low levels of $\mathrm{CH}_{4}$ being emitted from poultry litter. Since $\mathrm{CH}_{4}$ is produced by an anaerobic process and poultry litter is typically aerobic, high $\mathrm{CH}_{4}$ emissions are not expected. An increase in $\mathrm{CH}_{4}$ emissions was observed during the first 3 weeks ( 0 to $14 \mathrm{~d}$ ) of flock 2 and during the first 5 weeks ( 0 to $35 \mathrm{~d}$ ) for most treatments of flock 3 . The increase in the moisture of the litter (Table 2) played a role in the increase in $\mathrm{CH}_{4}$ emissions, especially during the third flock (Table 3). Miles et al. [8] also saw an increase in $\mathrm{CH}_{4}$ from placement of chicks until mid growout, corresponding to increased moisture. The negative $\mathrm{CH}_{4}$ fluxes observed during day 42 for both flocks was likely caused by a thick layer of cake that started forming during week 5 . The layer of cake acted as a barrier creating lower emissions of $\mathrm{CH}_{4}$ from the litter surface. Large variability in $\mathrm{CH}_{4}$ flux measurement within pens were also observed during this period since the cake did not cover the entire pen, and therefore, the $\mathrm{CH}_{4}$ flux was very much dependent on the placement of the flux chamber. There was no significant difference in average (Table 3) or cumulative $\mathrm{CH}_{4}$ (Figure 3) emissions observed between treatments for either flock. Eugene et al. [16] also did not report any significant differences in $\mathrm{CH}_{4}$ flux between untreated and alum-treated litter.

Table 3. Average methane flux $\left(\mathrm{mg} \mathrm{CH}_{4} \mathrm{~m}^{-2} \mathrm{hr}^{-1}\right)$ for flock 2 and 3 by treatment and sampling date.

\begin{tabular}{|c|c|c|c|c|c|c|c|c|}
\hline \multirow{2}{*}{ Treatment } & \multicolumn{7}{|c|}{ Day } & \multirow{2}{*}{ Avg. } \\
\hline & 0 & 7 & 14 & 21 & 28 & 35 & 42 & \\
\hline & \multicolumn{8}{|c|}{ Flock 2} \\
\hline Control & 32.0at & $44.4 \mathrm{a}$ & $81.8 \mathrm{a}$ & $38.1 \mathrm{a}$ & $22.2 \mathrm{a}$ & $20.4 \mathrm{a}$ & $-7.48 b$ & $33.1 \mathrm{a}$ \\
\hline $49 \mathrm{~kg}$ AMLA $/ 100 \mathrm{~m}^{2}$ incorporated & $25.7 \mathrm{a}$ & $34.5 \mathrm{ab}$ & $55.5 a$ & $47.1 \mathrm{a}$ & $32.3 a$ & $24.4 \mathrm{a}$ & $17.5 \mathrm{a}$ & $33.9 \mathrm{a}$ \\
\hline $98 \mathrm{~kg}$ AMLA $/ 100 \mathrm{~m}^{2}$ incorporated & $10.8 \mathrm{a}$ & $36.1 \mathrm{ab}$ & $73.9 \mathrm{a}$ & $44.3 \mathrm{a}$ & $23.9 a$ & $23.6 \mathrm{a}$ & $8.12 \mathrm{a}$ & $31.5 \mathrm{a}$ \\
\hline $98 \mathrm{~kg}$ AMLA/100 m² surface applied & $14.8 \mathrm{a}$ & $29.3 b$ & $82.0 \mathrm{a}$ & $41.3 a$ & $22.5 \mathrm{a}$ & $27.2 \mathrm{a}$ & $19.3 a$ & $33.9 \mathrm{a}$ \\
\hline \multirow[t]{2}{*}{$98 \mathrm{~kg}$ alum $/ 100 \mathrm{~m}^{2}$ incorporated } & $18.9 \mathrm{a}$ & $28.3 b$ & $78.4 \mathrm{a}$ & $42.7 \mathrm{a}$ & $27.0 \mathrm{a}$ & $13.6 \mathrm{a}$ & $14.2 \mathrm{a}$ & $31.9 \mathrm{a}$ \\
\hline & \multicolumn{8}{|c|}{ Flock 3} \\
\hline Control & $-7.15 b$ & $19.0 \mathrm{a}$ & $25.5 a$ & $35.5 a$ & $29.7 \mathrm{a}$ & $94.1 \mathrm{a}$ & $-167.2 \mathrm{a}$ & $4.21 \mathrm{a}$ \\
\hline $49 \mathrm{~kg}$ AMLA $/ 100 \mathrm{~m}^{2}$ incorporated & $-2.04 \mathrm{ab}$ & $15.7 \mathrm{a}$ & $21.4 a$ & $31.6 a$ & $46.4 \mathrm{a}$ & $94.1 \mathrm{a}$ & $-8.81 \mathrm{a}$ & $28.3 \mathrm{a}$ \\
\hline $98 \mathrm{~kg}$ AMLA $/ 100 \mathrm{~m}^{2}$ incorporated & $4.03 \mathrm{a}$ & $21.8 \mathrm{a}$ & $19.5 \mathrm{a}$ & $33.7 \mathrm{a}$ & $42.6 \mathrm{a}$ & $178.9 \mathrm{a}$ & $3.97 \mathrm{a}$ & $43.5 \mathrm{a}$ \\
\hline $98 \mathrm{~kg}$ AMLA $/ 100 \mathrm{~m}^{2}$ surface applied & $6.47 \mathrm{a}$ & $20.8 \mathrm{a}$ & $20.5 a$ & $28.0 \mathrm{a}$ & $55.3 a$ & $131.7 \mathrm{a}$ & $72.4 \mathrm{a}$ & $47.9 \mathrm{a}$ \\
\hline $98 \mathrm{~kg}$ alum $/ 100 \mathrm{~m}^{2}$ incorporated & $-7.00 \mathrm{~b}$ & $24.1 \mathrm{a}$ & $26.0 \mathrm{a}$ & $47.7 \mathrm{a}$ & $31.1 \mathrm{a}$ & $87.7 \mathrm{a}$ & $-1.98 \mathrm{a}$ & $29.7 \mathrm{a}$ \\
\hline
\end{tabular}

+ Values in columns followed by different letters indicate significant $(p<0.05)$ differences in means within each date and flock.

\subsection{Carbon Dioxide Emissions}

Carbon dioxide emissions were the highest of the three GHGs measured in this study, ranging from 10.1 to $47.3 \mathrm{~g} \mathrm{~m}^{-2} \mathrm{~h}^{-1}$ during flock 2 and from 0.18 to $50.5 \mathrm{~g} \mathrm{~m}^{-2} \mathrm{~h}^{-1}$ during flock 3 (Table 4$)$. At the start of flock $2(0 \mathrm{~d}), \mathrm{CO}_{2}$ emissions were still elevated from the previous flock (flock 1 ), which was removed only one week prior to the placement of flock 2 chicks. After the first week, $\mathrm{CO}_{2}$ levels decreased by more than half and then started increasing over the next 4 weeks ( 14 to $35 \mathrm{~d}$ ), corresponding to broiler growth. Average $\mathrm{CO}_{2}$ emissions on day 0 (of flock 3 ) were much lower compared to day 0 of flock 2 since 
a year had passed between the end of flock 2 and the beginning of flock 3 . As with flock 2 , flock $3 \mathrm{CO}_{2}$ emissions increased over the next 4 weeks (7 to $28 \mathrm{~d}$ ) corresponding to broiler growth. A study by Miles et al. [8] also reported increased $\mathrm{CO}_{2}$ levels in broiler houses over time with bird growth and respiration. The decrease in $\mathrm{CO}_{2}$ emissions on day 42 of flock 2 and days 35 and 42 of flock 3, was likely a result of caking that also affected $\mathrm{CH}_{4}$ emissions. During the 42-day broiler life cycle, averaged across flocks, $\mathrm{CO}_{2}$ represented $95 \%$ of total $\mathrm{GHG}$ emissions, while $\mathrm{CH}_{4}-\mathrm{CO}_{2}$-equivlant emissions accounted for $3 \%$ with $\mathrm{N}_{2} \mathrm{O}-\mathrm{CO}_{2}$-equivlant emissions making up the remaining $2 \%$. Alum mud litter amendment and alum did not influence average (Table 4) or cumulative $\mathrm{CO}_{2}$ flux (Figure 4) during either flock. Eugene et al. [16] found that adding alum to poultry litter significantly lowered $\mathrm{CO}_{2}$ emissions from poultry houses. Unlike this study, Eugene et al. [16] did not measure fluxes from litter but measured emissions from poultry houses that were either controls or treated with alum treatments, which included $\mathrm{CO}_{2}$ produced from propane heaters. The control poultry house had higher ventilation rates (because of high $\mathrm{NH}_{3}$ levels) which resulted in more propane being used to maintain optimum temperatures for poultry production, resulting in higher $\mathrm{CO}_{2}$ emissions compared to the poultry house with alum-treated litter [16].

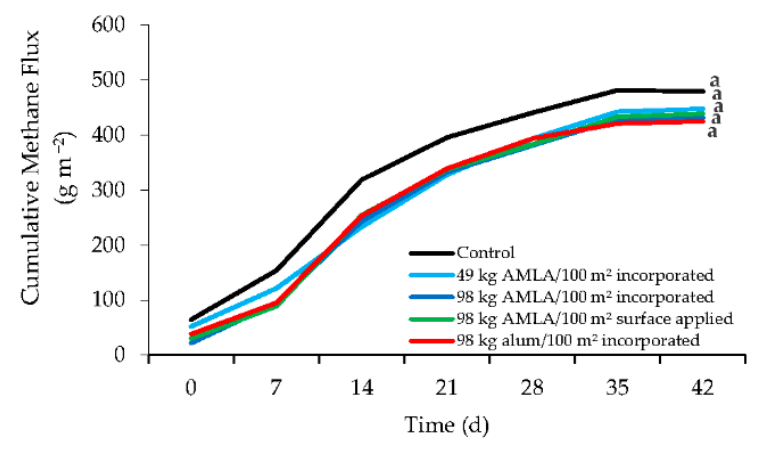

(a)

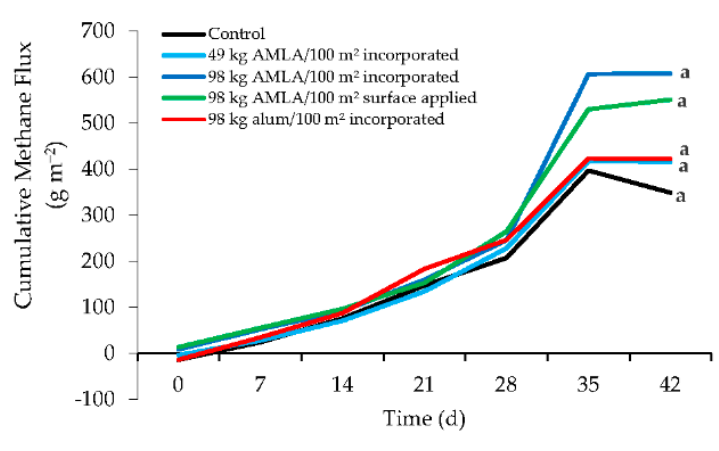

(b)

Figure 3. Cumulative methane flux $\left(\mathrm{g} \mathrm{CH}_{4} \mathrm{~m}^{-2}\right)$ for (a) flock 2 and (b) flock 3 as a function of time. Treatments on day 42 not sharing a common letter are significantly different $(p<0.05)$.

Table 4. Average carbon dioxide flux $\left(\mathrm{g} \mathrm{CO}_{2} \mathrm{~m}^{-2} \mathrm{hr}^{-1}\right)$ for flock 2 and 3 by treatment and sampling date.

\begin{tabular}{|c|c|c|c|c|c|c|c|c|}
\hline \multirow{2}{*}{ Treatment } & \multicolumn{7}{|c|}{ Day } & \multirow{2}{*}{ Avg } \\
\hline & $\mathbf{0}$ & 7 & 14 & 21 & 28 & 35 & 42 & \\
\hline & \multicolumn{8}{|c|}{ Flock 2} \\
\hline Control & 29.1at & $12.6 \mathrm{a}$ & $23.4 \mathrm{a}$ & $19.8 \mathrm{a}$ & $33.0 \mathrm{a}$ & $47.3 \mathrm{a}$ & $18.9 \mathrm{a}$ & $26.3 a$ \\
\hline $49 \mathrm{~kg}$ AMLA $/ 100 \mathrm{~m}^{2}$ incorporated & $27.5 \mathrm{a}$ & $13.2 \mathrm{a}$ & $24.2 \mathrm{a}$ & $21.9 \mathrm{a}$ & $41.7 \mathrm{a}$ & $41.0 \mathrm{a}$ & $18.9 \mathrm{a}$ & $26.9 \mathrm{a}$ \\
\hline $98 \mathrm{~kg}$ AMLA/100 $\mathrm{m}^{2}$ incorporated & $28.2 \mathrm{a}$ & $11.3 \mathrm{a}$ & $21.6 \mathrm{a}$ & $22.8 \mathrm{a}$ & $39.1 \mathrm{a}$ & $35.4 \mathrm{a}$ & $23.2 \mathrm{a}$ & $26.0 \mathrm{a}$ \\
\hline $98 \mathrm{~kg}$ AMLA/100 $\mathrm{m}^{2}$ surface applied & $29.0 \mathrm{a}$ & $10.1 \mathrm{a}$ & $19.9 a$ & $21.7 \mathrm{a}$ & $32.0 \mathrm{a}$ & $37.1 \mathrm{a}$ & $22.5 a$ & $25.0 \mathrm{a}$ \\
\hline \multirow[t]{2}{*}{$98 \mathrm{~kg}$ alum $/ 100 \mathrm{~m}^{2}$ incorporated } & $26.8 \mathrm{a}$ & $10.2 \mathrm{a}$ & $20.0 \mathrm{a}$ & $18.5 \mathrm{a}$ & $35.4 a$ & $41.1 \mathrm{a}$ & $18.5 a$ & $24.4 \mathrm{a}$ \\
\hline & \multicolumn{8}{|c|}{ Flock 3} \\
\hline Control & $0.61 \mathrm{a}$ & $1.25 \mathrm{a}$ & $18.3 \mathrm{a}$ & $42.9 \mathrm{a}$ & $40.4 \mathrm{a}$ & $29.7 \mathrm{a}$ & $21.6 a$ & $22.1 \mathrm{a}$ \\
\hline $49 \mathrm{~kg}$ AMLA $/ 100 \mathrm{~m}^{2}$ incorporated & $0.46 \mathrm{a}$ & $0.69 \mathrm{a}$ & $20.1 \mathrm{a}$ & $39.8 \mathrm{a}$ & $39.6 a$ & $25.7 \mathrm{a}$ & $17.6 \mathrm{a}$ & $20.6 \mathrm{a}$ \\
\hline $98 \mathrm{~kg}$ AMLA $/ 100 \mathrm{~m}^{2}$ incorporated & $0.25 \mathrm{a}$ & $0.50 \mathrm{a}$ & $19.8 \mathrm{a}$ & $45.0 \mathrm{a}$ & $50.5 \mathrm{a}$ & $25.5 \mathrm{a}$ & $17.5 \mathrm{a}$ & $22.7 \mathrm{a}$ \\
\hline $98 \mathrm{~kg}$ AMLA/100 $\mathrm{m}^{2}$ surface applied & $0.61 \mathrm{a}$ & $0.46 \mathrm{a}$ & $16.8 \mathrm{a}$ & $36.0 \mathrm{a}$ & $39.5 a$ & $22.4 \mathrm{a}$ & $14.4 \mathrm{a}$ & $18.6 \mathrm{a}$ \\
\hline $98 \mathrm{~kg}$ alum $/ 100 \mathrm{~m}^{2}$ incorporated & $0.18 \mathrm{a}$ & $0.79 a$ & $19.0 \mathrm{a}$ & $35.5 a$ & $43.4 \mathrm{a}$ & $25.3 a$ & $12.4 \mathrm{a}$ & $19.5 \mathrm{a}$ \\
\hline
\end{tabular}

t Values in columns followed by different letters indicate significant $(p<0.05)$ differences in means within each date and flock. 


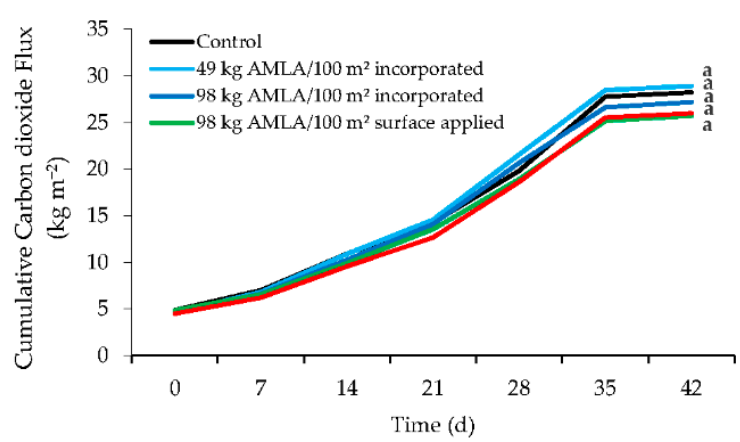

(a)

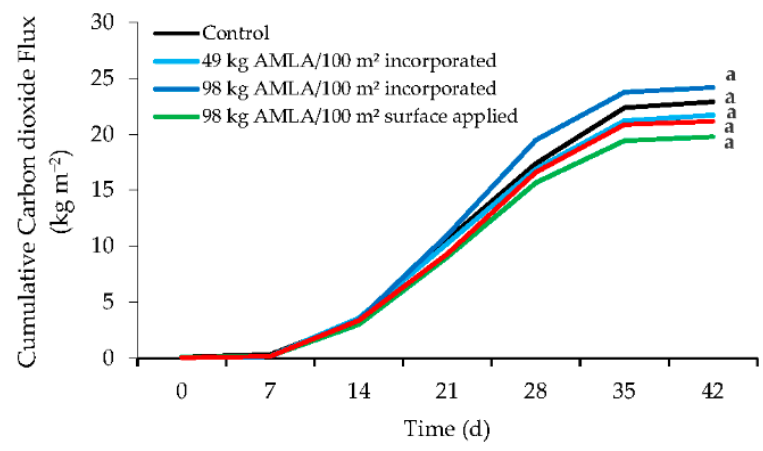

(b)

Figure 4. Cumulative carbon dioxide flux $\left(\mathrm{kg} \mathrm{CO}_{2} \mathrm{~m}^{-2}\right)$ for (a) flock 2 and (b) flock 3 as a function of time. Treatments on day 42 not sharing a common letter are significantly different $(p<0.05)$.

\subsection{Effect of Litter Accuulation on Greenhouse Gas Emissions}

In the United States, poultry litter is only cleaned out and replaced in poultry houses once a year, with some parts of the country cleaning out once every 3 to 5 years. The addition of fresh manure during new flocks affects GHG emissions in several ways. One of the primary ways is by adding organic compounds that are very labile, so there will be more microbial activity as they decompose the easily decomposable compounds. The rise in microbial activity will greatly increase $\mathrm{CO}_{2}$ production. If the litter is dry enough, some of the $\mathrm{NH}_{4}$ will be nitrified to $\mathrm{NO}_{3}$. As more and more manure builds up and the moisture content of the litter gets higher, particularly in the cake, oxygen diffusion into the litter will be slower than oxygen demand by microbes, causing anaerobic microsites to develop in the litter. When this happens, bacteria will begin to use $\mathrm{NO}_{3}$ as an electron acceptor, causing it to be denitrified ( $\mathrm{NO}_{3} \rightarrow \mathrm{NO}_{2} \rightarrow \mathrm{NO} \rightarrow \mathrm{N}_{2} \mathrm{O} \rightarrow \mathrm{N}_{2}$ ), a process that will likely increase $\mathrm{N}_{2} \mathrm{O}$ emissions. Under very reduced conditions, $\mathrm{CO}_{2}$ can be used by microbes as an electron acceptor for respiration, resulting in methanogenesis, which would cause an increase $\mathrm{CH}_{4}$ fluxes for the litter $\left(\mathrm{CO}_{2}+4 \mathrm{H}_{2} \rightarrow \mathrm{CH}_{4}+2 \mathrm{H}_{2} \mathrm{O}\right)$.

\section{Conclusions}

The objective of this study was to evaluate the effect of a new litter amendment, AMLA, on GHG emissions from poultry litter. Both $\mathrm{N}_{2} \mathrm{O}$ and $\mathrm{CH}_{4}$ emissions from the surface of poultry litter were low. The moisture content of the litter played a role in $\mathrm{NO}_{3}$ concentrations, with $\mathrm{NO}_{3}-\mathrm{N}$ observed to be near zero when the litter moisture was greater than $30 \%$. As the moisture increased during growout, $\mathrm{CH}_{4}$ emissions also increased. As expected, $\mathrm{CO}_{2}$ fluxes from the litter increased with broiler growth. The cake that formed during week 5 of both flocks caused greater variability in $\mathrm{CH}_{4}$ and $\mathrm{CO}_{2}$ emissions. Overall, the pen trial showed no significant differences in GHG emissions $\left(\mathrm{N}_{2} \mathrm{O}-\mathrm{N}, \mathrm{CH}_{4}\right.$, and $\left.\mathrm{CO}_{2}\right)$ being emitted from poultry litter treated with AMLA or alum compared to untreated litter. However, it is expected that the use of AMLA should reduce $\mathrm{CO}_{2}$ emissions from poultry facilities, as do other ammonia-control chemicals, such as alum, by lowering atmospheric $\mathrm{NH}_{3}$ levels in the houses, allowing lower ventilation rates during winter and concomitant decreases in propane use [16]. Since this novel poultry litter amendment was observed to have no significant impact on GHG emissions, addressing the concerns regarding the global warming potential of poultry production will require other strategies than those used to address air quality concerns.

Author Contributions: Conceptualization, P.A.M.J.; methodology, P.A.M.J.; validation, P.A.M.J.; formal analysis, K.A.; investigation, K.A., J.M., and P.A.M.J.; resources, P.A.M.J.; data curation, K.A. and J.M.; writing—original draft preparation, K.A.; writing—review and editing, P.A.M.J., K.A., J.M., and A.J.A.; supervision, P.A.M.J.; project administration, P.A.M.J.; funding acquisition, P.A.M.J. All authors have read and agreed to the published version of the manuscript. 
Funding: This research received no external funding.

Institutional Review Board Statement: The study was conducted according to the guidelines of the Declaration of Helsinki, and approved by the Institutional Review Board of Division of Agriculture IACUC protocol 18130 approved 1 June 2018.

Informed Consent Statement: Not applicable.

Data Availability Statement: Data are available upon request, email Philip.Moore@usda.gov.

Acknowledgments: The authors would like to thank Wally McDonner, Caleb Miller, Taylor Adams, and Scott Zornes, whose assistance at the farm was invaluable.

Conflicts of Interest: The authors declare no conflict of interest. Mention of a trade name, proprietary product, or specific equipment does not constitute a guarantee or warranty by the USDA and does not imply its approval or the exclusion of other products that may be suitable.

\section{References}

1. Ashworth, A.J.; Chastain, J.P.; Moore, P.A., Jr. Nutrient characteristics of poultry manure and litter. In Animal Manure: Production, Characteristics, Environmental Concerns and Management; Waldrip, H., Pagliari, P.H., He, Z., Eds.; Soil Science Society of America Monograph: Madison, WI, USA, 2019; pp. 63-88. [CrossRef]

2. USEPA. National Emission Inventory: Ammonia Emissions from Animal Husbandry; Revised Draft Report; USEPA: Washington, DC, USA, 2004.

3. Eggelston, H.S.; Buendia, L.; Miwa, K.; Ngara, T.; Tanabe, K. (Eds.) 2006 ICPP Guidelines for National Greenhouse Gas Inventories Hayama; Institute for Global Environmental Strategies: Hayama, Japan, 2006.

4. USEPA. Inventory of U.S. Greenhouse Gas Emissions and Sinks: 1990-2018; USEPA: Washington, DC, USA, 2020.

5. Meda, B.; Hassouna, M.; Aubert, C.; Robin, P.; Dourmad, J.Y. Influence of rearing conditions and manure management practices on ammonia and greenhouse gas emissions from poultry houses. World Poul. Sci. J. 2011, 67, 441-456. [CrossRef]

6. Stocker, T.F.; Qin, D.; Plattner, G.K.; Tignor, M.; Allen, S.K.; Boschung, J.; Nauels, A.; Xia, Y.; Bex, V.; Midgley, P.M. IPCC, 2013: Cimate Change 2013: The Physical Science Basis. Contribution of Working Group I to the Fifth Assessment Report of the Intergovernmental Panel on Climate Change; Cambrigdge University Preee Cambridge: Cambridge, UK; New York, NY, USA, $2013 ;$ p. 1535.

7. Moore, P.A., Jr.; Miles, D.; Burns, R.; Pote, D.; Berg, K.; Choi, I. Ammonia emission factors from broiler litter in barns, in storage, and after land application. J. Environ. Qual. 2011, 40, 1395-1404. [CrossRef] [PubMed]

8. Miles, D.M.; Owens, P.R.; Rowe, D.E. Spatial variability of litter gaseous flux within a commercial broiler house: Ammonia, nitrous oxide, carbon dioxide, and methane. Poult. Sci. 2006, 85, 167-172. [CrossRef] [PubMed]

9. Vergé, X.P.C.; Dryer, J.A.; Desjardins, R.L.; Worth, D. Long-term trends in greenhouse gas emission from the Canadian poultry industry. J. Appl. Poult. Res. 2009, 18, 210-222. [CrossRef]

10. Wathes, C.M.; Holden, M.R.; Sneath, R.P.; White, R.P.; Phillips, V.R. Concentrations and emission rates of aerial ammonia, nitrous oxide, methane, carbon dioxide, dust and endotoxin in UK broiler and layer houses. Br. Poult. Sci. 1997, 38, 14-28. [CrossRef] [PubMed]

11. Wang, S.; Huang, D. Assessment of greenhouse gas emissions from poultry enteric fermentation. Asian Australas. J. Anim. Sci. 2005, 18, 873-878. [CrossRef]

12. Sommer, S.G.; Dahl, P. Nutrient and carbon balance during the composting of deep litter. J. Argic. Eng. Res. 1999, 74, 145-153. [CrossRef]

13. Malomo, G.A.; Bolu, S.A.; Madugu, A.S.; Usman, Z.S. Nitrogen Emissions and Mitigation Strategies in Chicken Production. In Animal Husbandry and Nutrition; Yücel, B., Taşkin, T., Eds.; Intech Open: London, UK, 2018; pp. 43-62.

14. Carlile, F.S. Ammonia in poultry houses: A literature review. Worlds Poult. Sci. J. 1984, 40, 99-113. [CrossRef]

15. Calvet, S.; Cambra-López, M.; Estellés, F.; Torres, A.G. Characterization of gas emissions from a Mediterranean broiler farm. Poult. Sci. 2011, 90, 534-542. [CrossRef] [PubMed]

16. Eugene, B.; Moore, P.A., Jr.; Li, H.; Miles, D.; Trabue, S.; Burns, R.; Buser, M. Effects of alum additions to poultry litter on in-house ammonia and greenhouse gas concentrations and emissions. J. Environ. Qual. 2015, 44, 1530-1540. [CrossRef] [PubMed]

17. Moore, P.A., Jr. Composition and Methods of Treating Animal Manure. US Patent 9,301,440, 5 April 2016.

18. Adak, A.; Mallik, D.; Chaudhuri, S.K. Alum mud: Phase identification and catalytic potential for aquepis-phase decomposition of hydrogen peroxide. Clays Clay Miner. 1999, 47, 234-238. [CrossRef]

19. Moore, P.A., Jr. Development of a new manure amendment for reducing ammonia volatilization and phosphorus runoff from poultry litter. J. Environ. Qual. 2016, 45, 1412-1429. [CrossRef] [PubMed]

20. Anderson, K.; Moore, P.A., Jr.; Martin, J.; Ashworth, A.J. Effect of a new manure amendment on ammonia emissions from poultry litter. Atmosphere 2020, 11, 257. [CrossRef]

21. Choi, I.H.; Moore, P.A., Jr. Effects of liquid aluminum chloride additions to poultry litter on broiler performance, ammonia emissions, soluble phosphorus, total volatile fatty acids, and nitrogen contents of litter. Poult. Sci. 2008, 87, 1955-1963. [CrossRef] [PubMed] 
22. Self-Davis, M.L.; Moore, P.A., Jr. Method of determining water soluble phosphorus in animal manure. In Methods of Phosphorus Analysis for Soils, Sediments, Residuals, and Water; Southern Cooperative Series Bulletin No. 396, SERA-IEG 17; Pierzynski, G.M., Ed.; North Carolina State University: Raleigh, NC, USA, 2000; pp. 74-77. ISBN 1-58161-396-2.

23. USEPA. Methods for Chemical Analysis of Water and Wastes; USEPA Rep. 600/4-79-020. USEPA, Environ; Monitoring and Support Lab.: Cincinnati, OH, USA, 1983; USEPA Rep. 600/4-79-020. USEPA, Environ.

24. SAS Institute. SAS User's Guide: Statistics; SAS Inst.: Cary, NC, USA, 2014.

25. Moore, P.A., Jr.; Miles, D.M.; Burns, R.; Pote, D.; Berg, K. Evaluation and Management of Ammonia Emissions from Poultry Litter. In Best Management Practices, Proceedings of Workshop on Agricultural Air Quality: State of Science, Potomac, MA, USA, 5-8 June 2006; Aneja, V.P., Schlesinger, W.H., Knighton, R., Jennings, G., Niyogi, D., Gilliam, W., Duke, C.S., Eds.; North Carolina State University: Raleigh, NC, USA, 2006; pp. 304-310.

26. Chastain, J.P.; Camberato, J.J.; Skewes, P. Poultry Manure Production and Nutrient Content. Chapter 3b. In Confined Animal Manure Managers Certification Program Manual Poultry Version; Clemson University Extension: Clemson, SC, USA, 2001.

27. USEPA. Nitrification; USEPA: Washington, DC, USA, 2002.

28. Burns, R.T.; Li, H.; Xin, H.; Gates, R.S.; Overhults, D.G.; Earnest, J.; Moody, L. Greenhouse Gas (GHG) Emissions from Broiler House in the Southeastern United States. In Proceedings of the ASABE Annual International Meeting, St. Joseph, MI, USA, 29 June-2 July 2008. Paper No. 084649. 